\title{
A. V. KIDDER: THE FIRST VIKING FUND MEDALIST
}

$\mathrm{F}$ OR outstanding contributions to the field of American Archaeology, the Viking Fund Prize and Gold Medal in Archaeology ${ }^{1}$ have been awarded to A. V. Kidder, Chairman of the Division of Historical Research of the Carnegie Institution of Washington.

The citation which accompanies the award reads:

\section{TO Alfred VINCENT KIDDER:}

Your work at Pecos has been the foundation on which modern field methods have been built. The several Pecos conferences held under your supervision have pointed the way to cooperation and orderly research in the Southwest. Your "Introduction to the Study of Southwestern Archaeology" was the first comprehensive analytical and interpretative study of the archaeology of the Southwest, or of any region in America. The Papers of the Southwest Expedition, organized by you, and of which you are author or co-author of four volumes, is the outstanding series on an archaeological site in the American field.

As the head of the Division of Historical Research of the Carnegie Institution, you have developed a broad-scale anthropological program of research in the Maya area. In spite of the great amount of administrative work with which you have been faced, you have maintained a steady production of research papers in the Middle American field.

The Society for American Archaeology is proud to award to you the Viking Fund Prize and Medal for your outstanding work in the field of archaeology, and for your great influence in developing and stimulating individuals and programs of research in American Archaeology.

Kidder's many and varied contributions to his science began in the Southwest, where he went on his first field trip in 1907. His work in northeastern Arizona with S. J. Guernsey helped to clarify the distinctions between Basketmaker and Pueblo horizons. He went to Andover in 1915 to take charge of the Southwest Expedition of the Department of Archaeology of Phillips Academy, now called

1 Made available for the first time this year, a prize of one thousand dollars and a gold medal will be donated annually by the Viking Fund. Similar prizes and medals are being awarded in the fields of Cultural and Physical Anthropology. Each prize and medal is awarded by a committee of the appropriate society to that person, irrespective of nationality or geographical area in which he practices, who has, in the opinion of the committee, made the outstanding contribution to his branch of anthropology. The committee making the award in Archaeology included D.S. Byers (ex officio), H. B. Collins, G. F. Ekholm, F. Johnson, J. B. Griffin, E. W. Haury, H. O'N. Hencken, T. D. McCown, and G. R. Willey. the Robert S. Peabody Foundation. Excavations at Pecos, initiated in 1915, were continued until 1929, interrupted during 1917 and 1918 by the war from which Kidder returned a Captain of Infantry and a Chevalier, Légion d'Honneur. In 1929 he became Chairman of the Division of Historical Research of the Carnegie Institution of Washington, one of the most important positions in American Archaeology, which he continues to fill.

Stratigraphy as an archaeological technique, conceived in the Old World, and nurtured by Reisner in Egypt, faced its most severe tests in the New World when Kidder started work at Pecos. Nelson's investigations of ruins in the Gallisteo Basin, in New Mexico, began three years before and helped to formulate some of the problems. Hodge's work at Hawikuh was a contemporary venture. Thorough testing at Pecos proved the value of the method which is now the accepted basis for systematic research.

During the years when the Southwest Expedition was in the field, Kidder was responsible for the publication of various volumes of the Papers of the Southwest Expedition, including his "Introduction to the Study of Southwestern Archaeology," Guthe's "Pueblo Pottery Making," and Parsons" "Pueblo of Jemez," the last two designed as a background against which results of the excavations could be interpreted. The lucid and matter-of-fact presentation of this material, and the systematic approach, have done much to influence subsequent workers in the field.

Perhaps of even greater importance to the future of Archaeology in the Americas were the gatherings of anthropologists interested in the Southwest. They came to be known as the Pecos Conferences. At these conferences, common problems were discussed, and cooperative methods of research planned. The terminology for the cultural stages which was developed at Pecos, is still in general use, modified to a certain extent by later discoveries. Undoubtedly the underlying philosophy and the systematization of prehistory which were an outgrowth of these conferences have affected the thinking of archaeologists throughout the New World. Similar conferences have been held since then in many different fields of Archaeology.

Kidder left Andover in 1930 to become Chairman of the Division of Historical Re- 


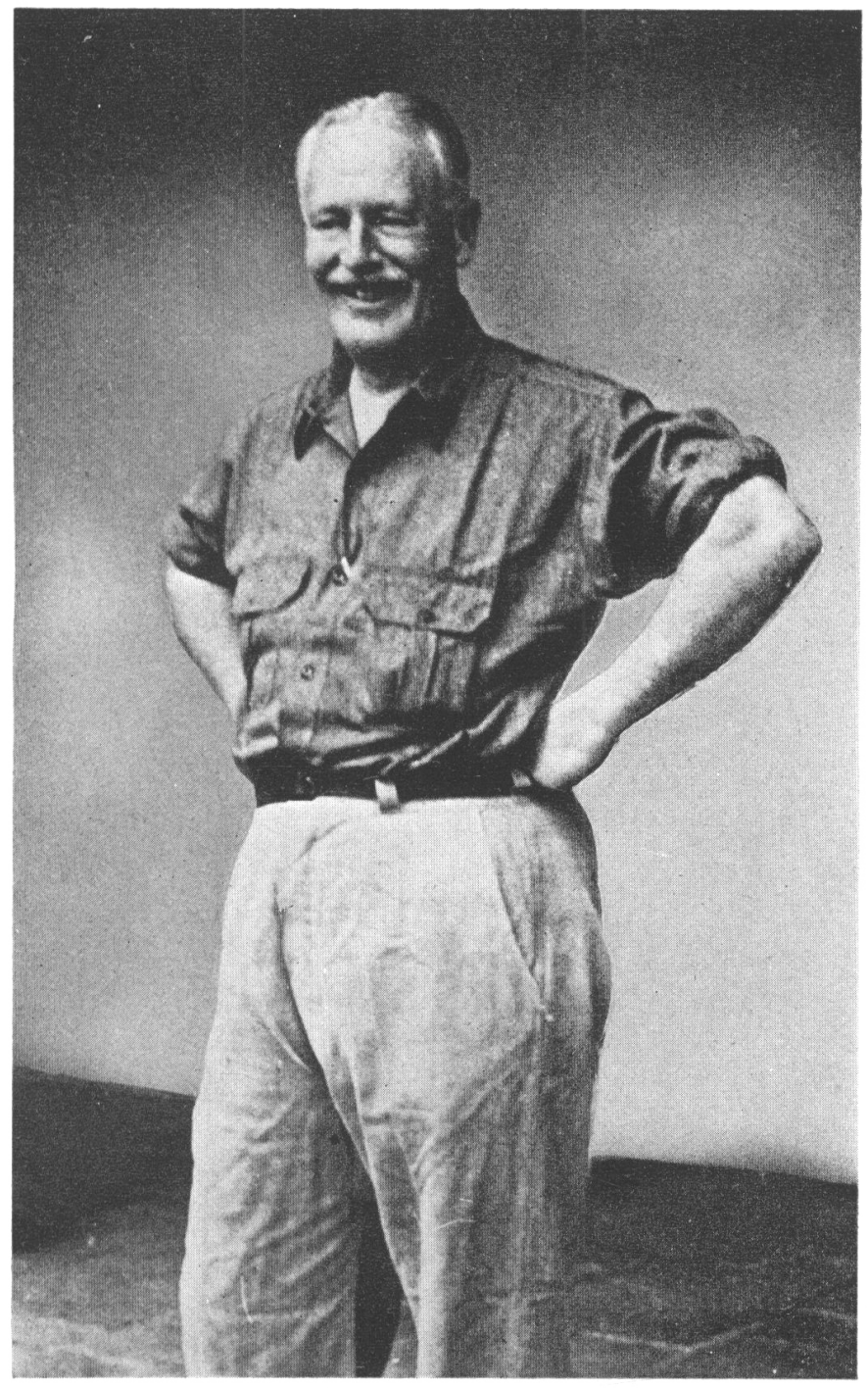

Alfred Vincent Kidder 
search, concerned with the history and archaeology of the New World with special emphasis on Middle America. At that time it was felt by many that art and architecture would provide the key to the prehistory of the Maya; restoration of buildings was common practice, and stratigraphy was of importance only as it was evident in architectural details. The striking exception was in the work of Vaillant, trained under Kidder at Pecos, whose trenches through refuse at Chichen Itza in 1926, and whose thesis on the chronological significance of Maya ceramics, completed in 1927, pointed a brilliant spotlight at the weakness in current -procedure.

In formulating a program for work in the Middle American field, Kidder has sought to shift the emphasis from the more spectacular side to study of general cultural stratigraphy and sites devoid of pretentious temples and pyramids. Though eschewing the most spectacular as such, he nevertheless has discovered some of the richest finds yet made in American Archaeology, in the tombs at Kaminaljuyu. Methods which he employed, and which his disciple, Vaillant, brought to Mexico, have been the key to our present understanding of the common basis of Middle American cultures.

Throughout his career the quiet reassurance and encouragement which he gives so freely to those who seek his advice have been of inestimable value in developing and stimulating not only individuals, but also programs of research in fields of Archaeology, many of them quite outside the ones in which he specializes.

American archaeologists will find it altogether fitting and proper that the first Viking Fund Prize and Medal be awarded to him. 